\title{
Survei Minat Siswa Kelas X SMA/Sederajat terhadap Ekstrakurikuler Pencak Silat
}

\author{
Widhi Yunariswan*, Eko Hariyanto \\ Universitas Negeri Malang, Jl. Semarang No. 5 Malang, Jawa Timur, Indonesia \\ *Penulis korespondensi, Surel: widhiyunariswan6@gmail.com
}

Paper received: 3-5-2021; revised: 24-5-2021; accepted: 28-5-2021

\begin{abstract}
Abstrak
Penelitian ini bertujuan untuk melihat minat siswa kelas X SMA/sederajat terhadap ekstrakurikuler pencak silat se-Kabupaten Ponorogo. Dalam penelitian ini populasi berjumlah 954 dan sampel yang diambil berjumlah 105 siswa. Instrumen yang digunakan adalah angket, sedangkan teknik analisis data menggunakan persentase/ Hasil penelitian menunjukkan minat siswa sebanyak 96 siswa (91 persen) memiliki minat dengan kategori sangat tinggi, sebanyak 9 siswa (9 persen) memiliki minat terhadap ekstrakurikuler pencak silat dangan kategori tinggi. Secara keseluruhan dapat disimpulkan bahwa survei minat siswa kelas X SMA/sederajat terhadap ekstrakurikuler pencak silat seKabupaten Ponorogo masuk dalam kategori sangat tinggi sebesar 91 persen. Penelitian ini bertujuan untuk melihat minat siswa kelas X SMA/sederajat terhadap ekstrakurikuler pencak silat seKabupaten Ponorogo. Dalam penelitian ini populasi berjumlah 954 dan sampel yang diambil berjumlah 105 siswa. Instrumen yang digunakan adalah angket, sedangkan teknik analisis data menggunakan persentase / Hasil penelitian menunjukkan minat siswa sebanyak 96 siswa (91 persen) memiliki minat dengan kategori sangat tinggi, sebanyak 9 siswa ( 9 persen) memiliki minat terhadap ekstrakurikuler pencak silat dangan kategori tinggi. Secara keseluruhan dapat disimpulkan bahwa survei minat siswa kelas X SMA/sederajat terhadap ekstrakurikuler pencak silat se-Kabupaten Ponorogo masuk dalam kategori sangat tinggi sebesar 91 persen.
\end{abstract}

Kata kunci: minat; ekstrakurikuler; pencak silat

\section{Pendahuluan}

Dalam kurikulum, program inti yang berhubungan dengan proses pendidikan disebut program kurikuler. Dalam proses pendidikan di sekolah, program kurikuler menjadi program inti yang dilaksanakan terjadwal secara pasti oleh sekolah dan dilaksanakan sesuai dengan kalender pendidikan nasional. Selain itu, program yang dinamakan program ekstrakurikuler sebagai penunjang dan membantu ketercapaian tujuan kurikuler/program inti. Dalam pencapaian tujuan pendidikan program ekstrakurikuler memiliki peran dan fungsi yang sangat penting. Program ekstrakurikuler bisa memberikan sesuatu yang tidak bisa diberikan dalam program kurikuler untuk mencapai tujuan pendidikan, sehingga program ekstrakurikuler mempunyai peranan yang sama penting dengan program kurikuler.

Salah satu program ekstrakurikuler yang berkaitan dengan mata pelajaran Pendidikan Jasmani, Olahraga dan Kesehatan adalah pencak silat. Ekstrakurikuler pencak silat sudah banyak dijalankan di sekolah-sekolah di Kabupaten Ponorogo, seperti SMAN 1 Ponorogo, SMAN 2 Ponorogo, SMKN 2 Ponorogo, SMA Muhammadiyah Ponorogo, SMA Bakti, SMK 1 PGRI Ponorogo, dan SMA Pemberdayaan Bangsa. Namun, tidak banyak siswa yang berminat untuk mengikuti ekstrakurikuler pencak silat di sekolah-sekolah tersebut. Rata-rata siswa yang berminat untuk mengikuti ekstrakurikuler pencak silat di sekolah-sekolah tersebut berkisar 8-15 siswa. Seperti yang diketahui banyak orang, banyak perguruan silat yang terdapat pada kabupaten ini. Bentrok antar perguruan pencak silat sering terjadi dan mengakibatkan rumah 
rusak (YouTube, 2012). Hal ini menjadi permasalahan yang membuat siswa maupun orang tua siswa enggan untuk mendaftar ataupun memperbolehkan anaknya untuk mengikuti ekstrakurikuler pencak silat. Namun, setelah terbentuknya Forum Komunikasi Pencak Silat dan Beladiri (FKPSB) pada tahun 2013, bentrok antar perguruan semakin berkurang bahkan sudah tidak pernah terjadi.

Perkembangan prestasi pencak silat di Kabupaten Ponorogo dari tahun ke tahun juga sudah mulai terlihat dari pertandingan-pertandingan yang sudah ada. Pada tahun 2015 atlet Kabupaten Ponorogo berhasil meraih 1 emas dan 1 perak pada pertandingan PORPROV JATIM V, pada tahun 2017 berhasil meraih 2 emas dan 1 perak pada International Pencak Silat PSHT Champhionship, pada tahun 2018 berhasil meraih juara umum 1 kategori remaja dan juara umum 2 untuk semua kategori dengan raihan 4 emas, 1 perak dan 1 perunggu pada pertandingan MENPORA CUP, dan masih banyak juara yang diraih oleh atlet pencak silat Ponorogo. Atlet pencak silat Kabupaten Ponorogo juga ada yang meraih juara 1 pada ASIAN GAMES 2018 dan juara 3 pada Kejuaraan Dunia di Belgia. Menurut penelitian Faridah (2017) salah satu faktor yang mempengaruhi minat siswa adalah keinginan untuk berprestasi dan keinginan untuk selalu maju. Dari perkembangan prestasi pencak silat di Kabupaten Ponorogo, minat siswa akan muncul karena pencak silat dapat menyalurkan keinginan siswa untuk berprestasi.

Namun setelah berkembangnya prestasi atlet-atlet Kabupaten Ponorogo, atlet-atlet Kabupaten Ponorogo disalurkan untuk melatih sekolah-sekolah yang terdapat ekstrakurikuler pencak silat, sehingga metode latihan yang digunakan tidak jauh berbeda dengan metode latihan yang digunakan pada pemusatan latihan atlet-atlet pencak silat Kabupaten Ponorogo. Metode latihan yang digunakan disesuaikan dengan jadwal latihan ekstrakurikuler pencak silat yang rata-rata dilakukan 2-3 kali dalam satu minggu supaya siswa ekstrakurikuler dapat berlatih dengan maksimal. Dari pertandingan antar pelajar se-Kabupaten Ponorogo, sekolah yang terdapat ekstrakurikuler pencak silat menjadi lebih unggul dari pada sekolah-sekolah yang tidak terdapat ekstrakurikuler pencak silat. Ekstrakurikuler pencak silat akan menjadi wadah dari keinginan siswa untuk berprestasi dan keinginan untuk selalu maju.

Dari perkembangan antar perguruan pencak silat Kabupaten Ponorogo yang semakin membaik dan pencapaian prestasi atlet-atlet pencak silat Kabupaten Ponorogo maupun prestasi yang diraih siswa yang mengikuti ekstrakurikuler pencak silat yang terus meningkat, penulis akan mencoba meneliti minat siswa kelas X SMA/sederajat yang belum pernah mengikuti pencak silat terhadap ekstrakurikuler pencak silat di Kabupaten Ponorogo.

Pencak silat adalah sistem beladiri yang diwariskan oleh nenek moyang yang perlu dilestarikan, dibina, dan dikembangkan sebagai budaya bangsa Indonesia (Kriswanto, 2015). Menurut Gunawan (2008) pencak silat adalah beladiri tradisional Indonesia yang bisa ditemukan hampir di seluruh wilayah Indonesia dan berakar dari budaya Melayu. Menurut Kriswanto (2015) pencak silat merupakan seni beladiri, sehingga di dalamnya terdapat unsur keindahan dan tindakan. Sedangkan menurut Rahayuni (2014) pencak silat didefinisikan sebagai pembelaan diri untuk menghindari diri dari serangan serta segala malapetaka.

Minat adalah suatu rasa ketertarikan dan rasa lebih suka pada suatu hal atau aktivitas, tanpa ada yang menyuruh dan dasarnya adalah penerimaan akan suatu hubungan antara diri sendiri dengan sesuatu di luar diri (Slameto, 2003). Minat dimaksudkan sebagai kemauan dan usaha untuk mempelajari dan mencari sesuatu, misalnya pada minat seniman: orang 
mempunyai bakat atau tidak pada seni, tetapi telah ada usaha aktif untuk mempelajari seni (Wiyono, 2004).

Ekstrakurikuler adalah kegiatan yang dilakukan oleh peserta didik sebagai perluasan dari kegiatan kurikulum yang dilakukan di luar jam belajar kurikulum standar dengan tujuan untuk mengembangkan bakat, minat, kepribadian serta kemampuan peserta didik yang lebih luas (Permendikbud, 2013). Sedangkan menurut Prihatin (2011) kegiatan ekstrakurikuler adalah kegiatan di luar jam pelajaran biasa dan pada waktu libur sekolah dengan tujuan memperluas pengetahuan siswa, mengenal hubungan antara berbagai mata pelajaran, menyalurkan bakat dan minat serta melengkapi upaya pembinaan manusia Indonesia seutuhnya yang dilakukan baik di dalam maupun di luar sekolah.

\section{Metode}

Berdasarkan latar belakang, maka rancangan penelitian ini menggunakan penelitian kuantitatif deskriptif dengan pendekatan survei. Penelitian dilakukan di SMAN 1 Ponorogo, SMAN 2 Ponorogo, SMKN 2 Ponorogo, SMA Muhammadiyah Ponorogo, SMA Bakti, SMK 1 PGRI Ponorogo, dan SMA Pemberdayaan Bangsa. Dalam penelitian ini, populasi yang digunakan adalah SMA/sederajat yang terdapat ekstrakurikuler pencak silat, dengan jumlah 954 siswa kelas X yang belum mengikuti pencak silat. Dari populasi tersebut diambil sampel dengan jumlah 105 siswa. Sehingga sampel yang akan diambil dalam penelitian ini adalah siswa kelas $\mathrm{X}$ SMA/sederajat se-Kabupaten Ponorogo yang belum mengikuti pencak silat dengan mengambil sampel 15 siswa setiap sekolah.

Teknik pengambilan sampel menggunakan teknik sampel acak sederhana. Prosedur yang digunakan dalam tahap pengumpulan data yaitu: (1) Langkah pertama yang dilakukan penulis adalah dengan cara mendatangi secara langsung sekolah-sekolah yang terdapat ekstrakurikuler pencak silat, kegiatan ini dilakukan untuk mengetahui keberadaan ekstrakurikuler pencak silat, (2) Setelah mengetahui data sekolah yang terdapat ekstrakurikuler pencak silat, maka tahap selanjutnya adalah (a) membuat surat ijin observasi ke Fakultas Ilmu Keolahragaan Universitas Negeri Malang dan membuat ijin dari sekolahsekolah yang terdapat ekstrakurikuler pencak silat, (b) membuat instrumen, (c) memvalidasi instrumen ke dosen pembimbing, (d) melakukan pengambilan data secara langsung terhadap responden dengan cara melakukan survei minat menggunakan angket, kemudian data yang diperoleh direkapitulasi, (e) dan yang terakhir adalah menyusun laporan.

Menurut Kusumawati (2015:103) instrumen penelitian adalah alat atau fasilitas yang digunakan oleh peneliti dalam mengumpulkan data agar pekerjaannya lebih mudah, dan hasilnya lebih baik, dalam arti lebih cermat, lengkap, dan sistematis sehingga mudah diolah. Ada empat langkah yang harus ditempuh untuk menyusun instrumen, keempat langkah tersebut adalah sebagai berikut: (1) mendefinisi konsep (2) menyidik faktor, adapun faktorfaktor yaitu intrinsik dan ekstrinsik (3) menyusun butir-butir pernyataan (4) justifikasi ahli. Butir-butir pernyataan disusun dengan menggunakan tolak ukur bagi setiap faktor. Untuk menghasilkan instrumen yang valid dan reliabel dalam mengumpulkan data, maka perlu dilakukan uji validitas dan uji reliabilitas terhadap instrumen yang digunakan.

\subsection{Uji validitas}

"Validitas instrumen lebih tepat diartikan sebagai derajat kedekatan hasil pengukuran dengan keadaan sebenarnya (kebenaran), bukan masalah sama sekali benar atau seluruhnya 
salah" (Winarno, 2013). Menurut Suharsimi (2014) rumus korelasi product moment dari pearson adalah sebagai berikut:

$r x y=\frac{\mathrm{N} \cdot \Sigma \mathrm{XY}-\Sigma \mathrm{X} \cdot \Sigma \mathrm{Y}}{\sqrt{\left(\mathrm{N} \cdot \Sigma \mathrm{X}^{2}-(\Sigma \mathrm{X})^{2}\right)\left(\left(\mathrm{N} \cdot \Sigma \mathrm{Y}^{2}-(\Sigma \mathrm{Y})^{2}\right)\right.}}$

Keterangan:

$r x y=$ Koefisien korelasi item soal

$\Sigma \mathrm{Y}=$ Jumlah skor total

$\Sigma \mathrm{X}=$ Jumlah skor item

$\Sigma \mathrm{Y}^{2}=$ Jumlah kuadrat skor total

$\Sigma \mathrm{X}^{2}=$ Jumlah kuardat item soal

$\mathrm{N}=$ Jumlah sampel

\subsection{Uji reliabilitas}

Menurut Winarno (2013) "reliabilitas instrumen diartikan sebagai keajegkan hasil dari instrumen tersebut." Instrumen dikatakan memiliki reliabilitas jika hasil pengukuran berkalikali terhadap subjek yang sama selalu menunjukkan hasil atau skor yang sama. Rumus Alpha Chonbach digunakan setelah menemukan jumlah varian butir dari total kemudian dimasukkan rumus sebagai berikut (Suharsimi, 2014):

$\mathrm{rn}=\left(\frac{K}{K-1}\right)\left(\frac{\Sigma \sigma^{2} b}{\sigma^{2} t}\right)$

Keterangan:

$\mathrm{rn}=$ Reliabilitas instrumen

$\Sigma \sigma^{2} \mathrm{~b}=$ Jumlah varian butir

$\mathrm{K}$ = Banyaknya butir instrumen

$\sigma^{2} \mathrm{t}=$ Varian total

Teknik analisis yang digunakan dalam penelitian ini adalah analisis data deskriptif kuantitatif dengan persentase. Menurut Kusumawati (2015) "penelitian deskriptif merupakan penelitian dimana pengumpulan data untuk mengetes pernyataan atau hipotesis yang berkaitan dengan keadaan dan kejadian sekarang."

Dalam penelitian ini, instrumen yang digunakan dalam penelitian ini adalah berupa angket. "Metode angket atau kuisioner adalah sejumlah pernyataan tertulis yang digunakan untuk memperoleh informasi dari responden dalam arti laporan tentang pribadinya, atau halhal yang dia ketahui" (Suharsimi, 2014). Agar data yang diperoleh dalam penelitian berupa data kuantitatif, maka setiap butir jawaban diberi skor dalam bentuk skala Likert yang telah dimodifikasi dengan alternatif jawaban sebagai berikut:

Tabel 1. Skala Skor

\begin{tabular}{llll}
\hline \multicolumn{1}{c}{ Butir (+) } & \multicolumn{1}{c}{ Butir (+) } \\
\hline a. & Sangat setuju, diberi skor $=3$ & a. & Sangat setuju, diberi skor = 0 \\
b. & Setuju, diberi skor $=2$ & b. & Setuju, diberi skor $=1$ \\
c. & Kurang setuju, diberi skor $=1$ & c. & Kurang setuju, diberi skor $=2$ \\
d. & Tidak setuju, diberi skor $=0$ & d. & Tidak setuju, diberi skor $=3$ \\
\hline
\end{tabular}


Pada pengategorian data, akan ditentukan terlebih dahulu kategori fungsi manajemen berdasarkan acuan klarifikasi kategori dengan empat skala.

Tabel 2. Pengkategorian Skor

(Sudijono, 2011)

\begin{tabular}{cll}
\hline No & Kategori & Rumus \\
\hline 1 & Sangat Tinggi & $\mathrm{X}>(\mathrm{Mi}+1 . \mathrm{Sdi})$ \\
2 & Tinggi & $\mathrm{Mi} \leq \mathrm{X} \leq(\mathrm{Mi}+1 . \mathrm{Sdi})$ \\
3 & Rendah & $\mathrm{Mi}-1 . \mathrm{Sdi} \leq \mathrm{X} \leq \mathrm{Mi}$ \\
4 & Sangat Rendah & $\mathrm{X}<(\mathrm{Mi}-1 . \mathrm{Sdi})$ \\
\hline
\end{tabular}

Setelah semua data terkumpul, langkah selanjutnya adalah menganalisis data sehingga data-data tersebut dapat ditarik kesimpulan. Teknik analisan data dalam penelitian ini menggunakan rumus persentase. Menurut Sudijono (2014:43) rumus yang digunakan adalah sebagai berikut:

$P=\frac{f}{N} \times 100 \%$

Keterangan:

$\mathrm{P}=$ Persentase

$f=$ Nilai sebenarnya

$\mathrm{N}=$ Number of Cases (jumlah frekuensi/banyaknya individu).

\section{Hasil dan Pembahasan}

\subsection{Hasil}

Tujuan penelitian ini adalah untuk mengetahui minat siswa terhadap kegiatan ekstrakurikuler pencak silat di Kabupaten Ponorogo. Siswa yang menjadi responden adalah siswa kelas X SMA/sederajat yang belum mengikuti pencak silat di dalam maupun di luar sekolah. Faktor-faktor yang mempengaruhi minat siswa terhadap kegiatan ekstrakurikuler di Kabupaten Ponorogo meliputi faktor intrinsik dan faktor ekstrinsik. Berikut akan dideskripsikan secara keseluruhan maupun deskripsi secara fungsi yang menjadi dasar survei minat siswa terhadap kegiatan ekstrakurikuler pencak silat di Kabupaten Ponorogo.

Survei minat siswa kelas X SMA/sederajat terhadap ekstrakurikuler pencak silat seKabupaten Ponorogo secara keseluruhan diukur menggunakan angket atau kuisioner yang terdiri dari 30 pernyataan. Hasil penelitian dari 105 responden nantinya akan dimaksukkan ke dalam tabel penelitian. Data keseluruhan yang diperoleh dari responden adalah sebagai berikut:

Tabel 3. Data Skor yang Diperoleh dari Sampel

\begin{tabular}{ccccccc}
\hline $\mathbf{N}$ & Rata-rata & Nilai Maks & Nilai Min & Median & Modus & SD \\
\hline 105 & 74,676 & 90 & 49 & 76 & 75 & 8,824 \\
\hline
\end{tabular}

Berdasarkan data yang diperoleh dari survei minat siswa kelas X SMA/sederajat terhadap ekstrakurikuler pencak silat se-Kabupaten Ponorogo masuk dalam kategori sangat tinggi $(X>60)$ dengan nilai rata-rata 74,676. Selanjutnya akan dikategorikan menjadi 4 
kategori sangat tinggi, tinggi, rendah, dan sangat rendah berdasarkan mean dan standar deviasi. Mengacu pada kategori kecenderungan tersebut, maka distribusi frekuensi survei minat siswa kelas X SMA/sederajat terhadap ekstrakurikuler pencak silat se-Kabupaten Ponorogo berdasarkan tanggapan subjek penelitian dapat diketahui.

Tabel 4. Data Skor yang Diperoleh dari Sampel

\begin{tabular}{ccccc}
\hline No & Kelas Interval & Kategori & Frekuensi & Persentase \\
\hline 1 & $\mathrm{x}>60$ & Sangat Tinggi & 96 & $91 \%$ \\
2 & $45-60$ & Tinggi & 9 & $9 \%$ \\
3 & $30-45$ & Rendah & 0 & $0 \%$ \\
4 & $\mathrm{x}<30$ & Sangat Rendah & 0 & $0 \%$ \\
& & Total & 105 & $100 \%$ \\
\hline
\end{tabular}

Dari tabel di atas diperoleh survei minat siswa kelas X SMA/sederajat terhadap ekstrakurikuler pencak silat se-Kabupaten Ponorogo sebanyak 96 siswa (91\%) memiliki minat terhadap ekstrakurikuler pencak silat dalam kategori sangat tinggi dan sebanyak 9 siswa (9\%) memiliki minat terhadap ekstrakurikuler pencak silat dalam kategori tinggi. Nilai rata-rata sebesar 74,676 terletak pada interval $X>60$, serta frekuensi tertinggi juga terdapat pada interval X > 60 sebesar 91\%, maka survei minat siswa kelas X SMA/sederajat terhadap ekstrakurikuler pencak silat se-Kabupaten Ponorogo secara keseluruhan memperoleh kategori sangat tinggi. Untuk memperjelas deskripsi data penelitian survei minat siswa kelas X SMA/sederajat terhadap ekstrakurikuler pencak silat se-Kabupaten Ponorogo akan disajikan dalam gambar diagram batang. Berikut sajian gambar diagram batang yang diperoleh:

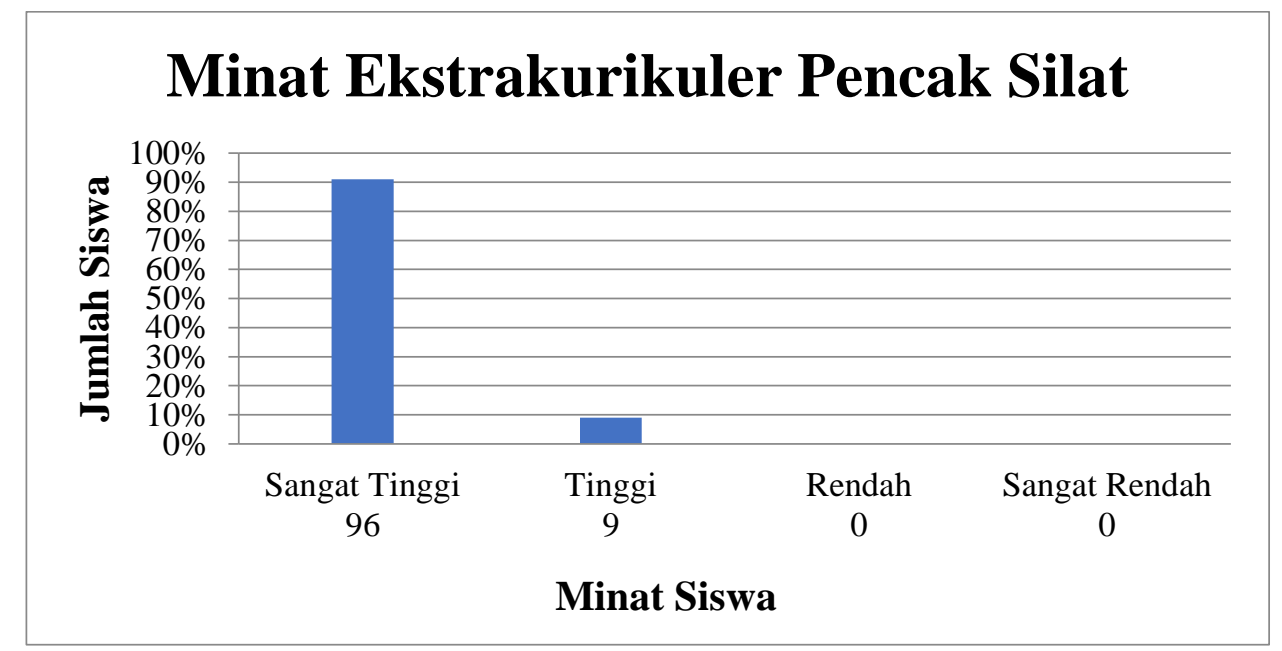

\section{Gambar 1. Histogram Survei Minat Siswa Kelas X SMA/Sederajat Terhadap Ekstrakurikuler Pencak Silat}

Berikut ini akan dideskripsikan data mengenai masing-masing indikator yang mendasari minat siswa kelas X SMA/sederajat terhadap ekstrakurikuler pencak silat seKabupaten Ponorogo. 


\subsubsection{Intrinsik}

Intrinsik atau minat yang berasal dari diri seseorang adalah salah satu faktor yang terdapat dalam survei minat siswa kelas X SMA/sederajat terhadap ekstrakurikuler pencak silat se-Kabupaten Ponorogo. Pada penelitian ini, faktor intrinsik terdiri dari 4 indikator yaitu perhatian, ketertarikan, kemauan, dan perbuatan. Pada penelitian ini faktor intrinsik dijabarkan menjadi 13 item pernyataan yang telah dinyatakan valid dan layak digunakan dalam penelitian survei minat siswa kelas X SMA/sederajat terhadap ekstrakurikuler pencak silat se-Kabupaten Ponorogo. Hasil penelitian yang diperoleh dari keseluruhan responden adalah sebagai berikut:

Tabel 5. Data Skor Intrinsik yang Diperoleh dari Sampel

\begin{tabular}{ccccccc}
\hline $\mathbf{N}$ & Rata-rata & Nilai Maks & Nilai Min & Median & Modus & SD \\
\hline 105 & 32,161 & 39 & 20 & 33 & 35 & 4,697 \\
\hline
\end{tabular}

Selanjutnya akan dikategorikan menjadi 4 kategori sangat tinggi, tinggi, rendah, sangat rendah berdasarkan mean dan standar deviasi. Mengacu pada kategorisasi kecenderungan, maka distribusi frekuensi survei minat siswa kelas X SMA/sederajat terhadap ekstrakurikuler pencak silat se-Kabupaten Ponorogo berdasarkan faktor intrinsik dapat diketahui. Tabel 4.4 berikut merupakan distribusi frekuensi survei minat siswa kelas X SMA/sederajat terhadap ekstrakurikuler pencak silat se-Kabupaten Ponorogo berdasarkan faktor intrinsik.

Tabel 6. Distribusi Survei Minat Siswa Kelas X SMA/Sederajat Terhadap Ekstrakurikuler Pencak Silat Se-Kabupaten Ponorogo

\begin{tabular}{ccccc}
\hline No & Kelas Interval & Kategori & Frekuensi & Persentase \\
\hline 1 & $\mathrm{X}>26$ & Sangat Tinggi & 92 & $88 \%$ \\
2 & $19,5-26$ & Tinggi & 13 & $12 \%$ \\
3 & $13-19,5$ & Rendah & 0 & $0 \%$ \\
4 & $\mathrm{X}<13$ & Sangat Rendah & 0 & $0 \%$ \\
& & Total & 105 & $100 \%$ \\
\hline
\end{tabular}

Dari tabel di atas, diperoleh survei minat siswa kelas X SMA/sederajat terhadap ekstrakurikuler pencak silat se-Kabupaten Ponorogo sebanyak 92 siswa (88\%) memiliki minat terhadap ekstrakurikuler pencak silat dalam kategori sangat tinggi dan sebanyak 13 siswa (12\%) memiliki minat terhadap ekstrakurikuler pencak silat dalam kategori tinggi. Frekuensi terbanyak sebesar $88 \%$ yaitu pada kategori sangat tinggi, maka minat siswa kelas $\mathrm{X}$ SMA/sederajat terhadap ekstrakurikuler pencak silat se-Kabupaten Ponorogo berdasarkan faktor intrinsik dalam kategori sangat tinggi. Apabila digambarkan dalam bentuk diagram batang adalah sebagai berikut: 


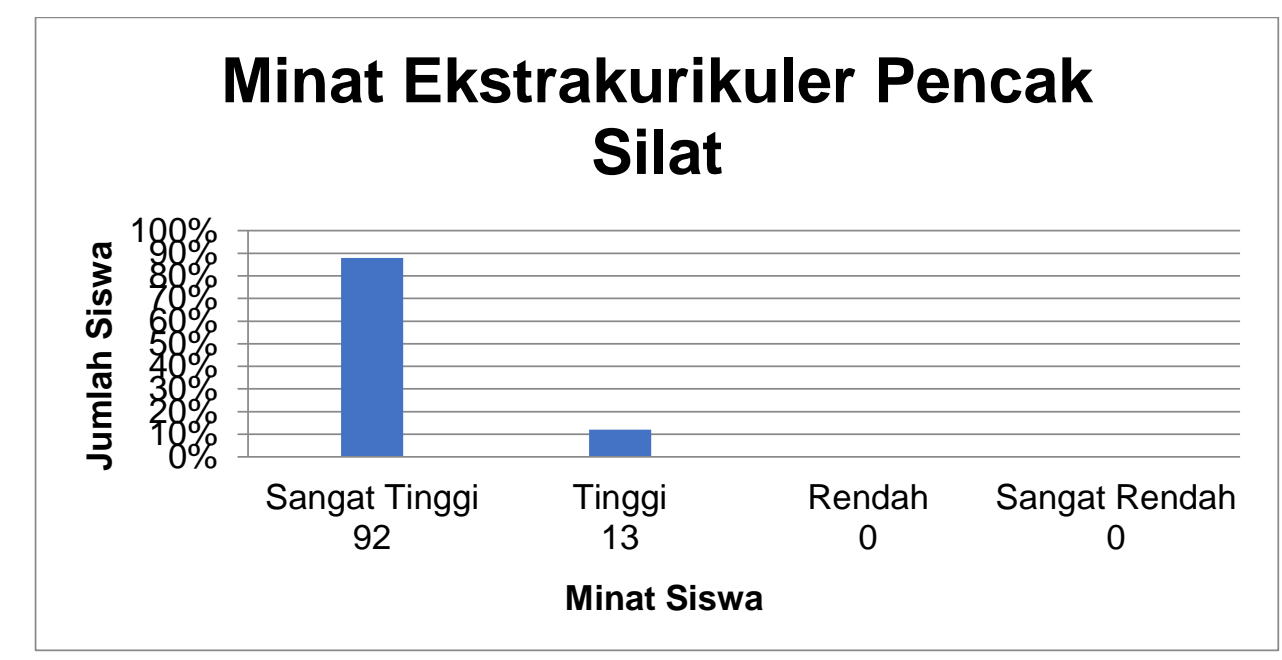

Gambar 2. Histogram Survei Minat Siswa Kelas X SMA/Sederajat Terhadap Ekstrakurikuler Pencak Silat Se-Kabupaten Ponorogo Berdasarkan Faktor Intrinsik

\subsubsection{Ekstrinsik}

Ekstrinsik atau minat yang berasal dari luar diri seseorang adalah salah satu faktor yang terdapat dalam survei minat siswa kelas X SMA/sederajat terhadap ekstrakurikuler pencak silat se-Kabupaten Ponorogo. Pada penelitian ini, faktor ekstrinsik terdiri dari 4 indikator yaitu pelatih, sarana dan prasarana, keluarga, lingkungan. Dalam penelitian ini faktor ekstrinsik dijabarkan dalam 17 item pernyataan yang telah dinyatakan valid dan layak digunakan sebagai instrumen penelitian survei minat siswa kelas X SMA/sederajat terhadap ekstrakurikuler pencak silat se-Kabupaten Ponorogo. Hasil penelitian yang diperoleh dari keseluruhan responden adalah sebagai berikut:

Tabel 7. Data Skor Faktor Ekstrinsik yang Diperoleh dari Sampel

\begin{tabular}{ccccccc}
\hline $\mathbf{N}$ & Rata-rata & Nilai Maks & Nilai Min & Median & Modus & SD \\
\hline 105 & 42,552 & 51 & 26 & 43 & 45 & 4,963 \\
\hline
\end{tabular}

Selanjutnya akan dikategorikan menjadi 4 kategori sangat tinggi, tinggi, rendah, sangat rendah berdasarkan mean dan standar deviasi. Mengacu pada kategorisasi kecenderungan tersebut, maka distribusi frekuensi survei minat siswa kelas X SMA/sederajat terhadap ekstrakurikuler pencak silat se-Kabupaten Ponorogo berdasarkan faktor ekstrinsik dapat diketahui. Tabel 4.6 berikut merupakan distribusi frekuensi survei minat siswa kelas $\mathrm{X}$ SMA/sederajat terhadap ekstrakurikuler pencak silat se-Kabupaten Ponorogo berdasarkan faktor ekstrinsik.

Tabel 8. Distribusi Survei Minat Siswa Kelas X SMA/Sederajat Terhadap Ekstrakurikuler Pencak Silat Se-Kabupaten Ponorogo

\begin{tabular}{ccccc}
\hline No & Kelas Interval & Kategori & Frekuensi & Persentase \\
\hline 1 & $\mathrm{X}>34$ & Sangat Tinggi & 98 & $93 \%$ \\
\hline 2 & $25,5-34$ & Tinggi & 7 & $7 \%$ \\
\hline
\end{tabular}




\begin{tabular}{ccccc}
\hline No & Kelas Interval & Kategori & Frekuensi & Persentase \\
\hline 3 & $17-25,5$ & Rendah & 0 & $0 \%$ \\
\hline 4 & $\mathrm{X}<17$ & Sangat Rendah & 0 & $0 \%$ \\
\hline & & TOTAL & 105 & $100 \%$ \\
\hline
\end{tabular}

Dari tebel di atas, diperoleh survei minat siswa kelas X SMA/sederajat terhadap ekstrakurikuler pencak silat se-Kabupaten Ponorogo sebanyak 98 siswa (93\%) memiliki minat terhadap ekstrakurikuler pencak silat dalam kategori sangat tinggi dan sebanyak 7 siswa (7\%) memiliki minat terhadap ekstrakurikuler pencak silat dalam kategori tinggi. Frekuensi terbanyak sebesar 93\% yaitu pada kategori sangat tinggi, maka minat siswa kelas $\mathrm{X}$ SMA/sederajat terhadap ekstrakurikuler pencak silat se-Kabupaten Ponorogo berdasarkan faktor ekstrinsik dalam kategori sangat tinggi. Apabila digambarkan dalam bentuk diagram batang adalah sebagai berikut:

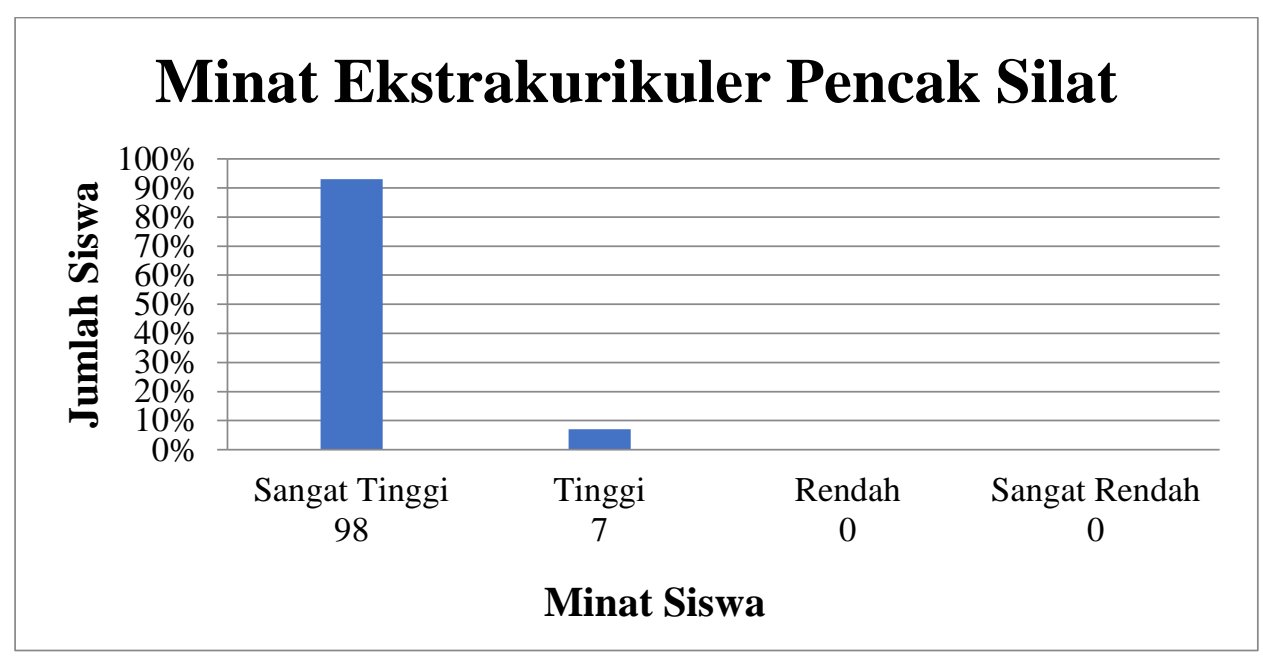

Gambar 3. Histogram Survei Minat Siswa Kelas X SMA/Sederajat Terhadap Ekstrakurikuler Pencak Silat Se-Kabupaten Ponorogo Berdasarkan Faktor Ekstrinsik

\subsection{Pembahasan}

Minat siswa dalam penelitian tentang minat siswa kelas X SMA/sederajat terhadap ekstrakurikuler pencak silat se-Kabupaten Ponorogo ini meneliti tentang kecenderungan atau keinginan siswa yang dipengaruhi oleh faktor intrinsik yang meliputi perhatian, ketertarikan, kemauan, perbuatan maupun faktor ekstrinsik yang meliputi pelatih, sarana dan prasarana, keluarga, lingkungan. Dengan mempunyai minat yang tinggi siswa akan terdorong untuk mencapai sasaran dan tujuannya karena sadar akan kebaikan, kepentingan, dan manfaatnya. Bagi siswa, minat sangat penting karena dapat menggerakkan perilaku siswa ke arah positif sehingga mampu menghadapi segala tuntutan, kesulitan, serta menanggung resiko dalam studinya. Minat dapat menentukan baik tidaknya siswa dalam mencapai tujuan sehingga semakin besar minat yang dimiliki siswa maka semakin besar pula kesuksesan belajarnya.

Dari hasil analisis yang telah dilakukan menunjukkan bahwa minat siswa kelas X SMA/ se-Kabupaten Ponorogo diketahui 96 siswa (91\%) siswa mempunyai minat sangat tinggi, 9 (9\%) siswa mempunyai minat tinggi, 0 siswa mempunyai minat rendah, dan 0 siswa mempunyai minat sangat rendah terhadap ekstrakurikuler pencak silat. 
Untuk pembahasan tiap-tiap faktor yang terkait dengan survei minat siswa kelas $\mathrm{X}$ SMA/sederajat terhadap ekstrakurikuler pencak silat se-Kabupaten Ponorogo yaitu intrinsik dan ekstrinsik berikut penjabarannya:

\subsubsection{Intrinsik}

Survei minat siswa kelas X SMA/sederajat terhadap ekstrakurikuler pencak silat seKabupaten Ponorogo berdasarkan faktor intrinsik memperoleh kategori sangat tinggi atau sebesar 88\%. Intrinsik adalah minat yang berasal dari dalam diri seseorang, ada beberapa faktor dari dalam yang mempengaruhi minat siswa terhadap ekstrakurikuler pencak silat yaitu perhatian, ketertarikan, kemauan dan perbuatan. Faktor intrinsik berpengaruh besar terhadap minat siswa karena memberikan dorongan dari dalam diri siswa dalam mencapai sasaran atau tujuannya.

Perhatian siswa terhadap ekstrakurikuler pencak silat sangat tinggi, hal ini ditunjukkan bahwa siswa mencoba mencari tahu informasi mengenai kegiatan ekstrakurikuler pencak silat, siswa juga memperhatikan dan mengamati kegiatan ekstrakurikuler pencak silat yang ada di sekolahnya. Ketertarikan siswa juga ditunjukkan dengan perasaan senang jika mengikuti kegiatan ekstrakurikuler pencak silat karena menurut siswa kegiatan ekstrakurikuler pencak silat menarik dan dapat menghilangkan kejenuhan. Siswa mempunyai kehendak dan mau mengikuti ekstrakurikuler pencak silat menunjukkan siswa mempunyai kemauan dan mau berbuat.

Penelitian ini selaras dengan penelitian Cahyono (2017:7) yang menemukan bahwa faktor intrinsik sangat besar pengaruhnya terhadap minat siswa dalam mengikuti ekstrakurikuler olahraga dan melakukan aktivitas olahraga dengan rasa tertarik terhadap olahraga

Dari hasil yang dipaparkan di atas dapat disimpulkan bahwa siswa kelas $\mathrm{X}$ SMA/sederajat se-Kabupaten Ponorogo mempunyai perhatian, ketertarikan, kemauan dan perbuatan terhadap ekstrakurikuler pencak silat. Dimana faktor dari dalam diri siswa sangat tinggi terhadap ekstrakurikuler pencak silat sehingga perhatian, ketertarikan, kemauan dan perbuatan muncul pada siswa.

\subsubsection{Ekstrinsik}

Survei minat siswa kelas X SMA/sederajat terhadap ekstrakurikuler pencak silat berdasarkan faktor ekstrinsik memperoleh kategori sangat tinggi atau sebesar 93\%. Ekstrinsik adalah minat yang berasal dari luar diri seseorang, ada beberapa faktor dari luar yang mempengaruhi minat siswa terhadap ekstrakurikuler pencak silat yaitu pelatih, sarana dan prasarana, keluarga, lingkungan. Faktor dari luar juga dapat membantu mendorong siswa untuk mencapai sasaran atau tujuannya.

Faktor ekstrinsik yang mempengaruhi siswa terhadap ekstrakurikuler pencak silat sangat tinggi ditunjukkan dari pengamatan siswa terhadap pelatih dan sarana prasarananya. Pelatih berkompeten yang selalu menanamkan sikap disiplin, memberikan teguran dan sarana prasarana kegiatan ekstrakurikuler pencak silat yang memadai menimbulkan minat siswa yang sangat tinggi. Dalam penelitian ini peran orang tua atau keluarga juga mempengaruhi besarnya minat siswa terhadap ekstrakurikuler pencak silat. Lingkungan sekolah dan 
lingkungan tempat tinggal terdapat kegiatan pencak silat juga memberikan dorongan timbulnya minat siswa.

Penelitian ini juga selaras dengan penelitian Hardiyanti (2019:8) yang menemukan bahwa minat terhadap bolabasket harus didukung dengan lingkungan yang kondusif, teman, guru, pelatih, sarana dan prasarana yang menunjang untuk dapat melaksanakan kegiatan ekstraurikuler yang baik.

Dari hasil yang dipaparkan di atas dapat disimpulkan bahwa siswa kelas $\mathrm{X}$ SMA/sederajat memperoleh kategori sangat tinggi, hal ini ditunjukkan dengan siswa yang selalu mengamati pelatih berkompeten yang menanamkan sikap disiplin, sarana prasarana yang memadai dan juga dorongan keluarga dan lingkungan sekitar.

Berdasarkan uraian di atas, secara keseluruhan survei minat siswa kelas $\mathrm{X}$ SMA/sederajat terhadap ekstrakurikuler pencak silat se-Kabupaten Ponorogo memperoleh kategori sangat tinggi. Sementara dari penjabaran faktor intrinsik dan ekstrinsik juga memperoleh kategori sangat tinggi. Dengan demikian pihak sekolah agar mempertahankan minat siswa terhadap ekstrakurikuler pencak silat, sementara pelatih ekstrakurikuler untuk menyusun atau merancang metode latihan karena sangat tingginya minat siswa terhadap ekstrakurikuler pencak silat.

\section{Simpulan}

Berdasarkan hasil penelitian maka diperoleh minat siswa kelas X SMA/sederajat terhadap ekstrakurikuler pencak silat se-Kabupaten Ponorogo sebanyak 96 siswa (91\%) memiliki minat terhadap ekstrakurikuler dengan kategori sangat tinggi, sebanyak 9 siswa (9\%) memiliki minat terhadap ekstrakurikuler pencak silat dengan kategori tinggi. Secara rinci dapat dipaparkan setiap faktornya, pada faktor intrinsik siswa yang masuk kategori sangat tinggi sebanyak 92 siswa (88\%), pada faktor ekstrinsik siswa yang masuk kategori sangat tinggi sebanyak 98 siswa (93\%). Secara keseluruhan dapat ditarik hasilnya bahwa survei minat siswa kelas X SMA/sederajat terhadap ekstrakurikuler pencak silat se-Kabupaten Ponorogo masuk dalam kategori sangat tinggi sebesar $91 \%$.

Berdasarkan paparan hasil penelitian dan kesimpulan yang telah dilakukan, maka adanya saran yang dianjurkan dalam penelitian ini adalah sebagai berikut: 1) Dengan adanya penelitian ini diharapkan pihak sekolah meningkatkan kegiatan ekstrakurikuler pencak silat, baik dalam pengelolaan maupun fasilitas demi kemajuan dan meningkatnya kualitas keterampilan ekstrakurikuler pencak silat sehingga nantinya dapat berprestasi dan mengharumkan nama sekolah. 2)Dengan adanya penelitian ini diharapkan pelatih lebih meningkatkan pengelolaan ekstrakurikuler pencak silat, baik dalam menyusun metode latihan maupun pendekatan terhadap siswa ekstrakurikuler pencak silat agar siswa merasa senang dan tidak bosan dalam mengikuti kegiatan ekstrakurikuler pencak silat.

\section{Daftar Rujukan}

Cahyono, N. D. (2017). Minat Siswa Dalam Mengikuti Kegiatan Ekstrakurikuler Olahraga Di Sekolah Menengah Atas Negeri 2 Playen Kabupaten Gunungkidul. Pendidikan Jasmani Kesehatan Dan Rekreasi, 5(5). Retreived from http://journal.student.uny.ac.id/ojs/index.php/pjkr/article/view/6692

Faridah, E. (2017). Minat Olahraga Renang pada Siswa Sekolah Menengah Atas (SMAN) Se Kabupaten Semarang. Jurnal Segar, 5(2), 50-54. Retreived from http://journal.unj.ac.id/unj/index.php/segar/article/download/4561/3424/

Gunawan, G. A. (2008). Teks Dan Ilustrasi Beladiri. Kantor Kementerian Negara Pemuda Dan Olahraga. 
Hardiyanti, U. (2019). Survei Motivasi Dalam Mengkuti Ekstrakurikuler Olahraga Bolabasket SMA Negeri 11 Makassar. Journal of Physical Education, Sport and Recreation, 1-10. Retrieved from http://eprints.unm.ac.id/16210/1/jurnal.pdf

Kriswanto, E. S. (2015). Pencak silat. Pustaka Baru Press.

Kusumawati, M. (2015). Penelitian Pendidikan Pendidikan Jasmani Olahraga Dan Kesehatan. PT. Alfabeta.

Permendikbud. (2013). Implementasi Kurikulum. Kementrian Pendidikan dan Kebudayaan.

Prihatin, E. (2011). Manajemen Peserta Didik (1st ed.). PT. Alfabeta.

Slameto. (2003). Belajar Dan Faktor-Faktor Yang Mempengaruhinya. PT. Rineka Cipta.

Sudijono, A. (2011). Pengantar Evaluasi Pendidikan. PT. Raja Grafindo Persada.

Sudijono, A. (2014). Pengantar Statiskik Pendidikan. PT. Raja Grafindo Persada.

Suharsimi, A. (2014). Prosedur Penelitian Suatu Pendekatan Praktek. PT. Rineka Cipta.

Winarno, M. E. (2013). Metode Penelitian Pendidikan Jasmani \& Olahraga. Universitas Negeri Malang (UM PRESS).

Wiyono, S. (2004). Manajemen Potensi Diri. PT. Gramedia Widiasarana Indonesia.

YouTube. (2012). Dua Perguruan Silat Bentrok. (Online), (https://www.youtube.com/watch?v=FqjVguA-7eQ). Diakses pada 19 Desember 2019. 